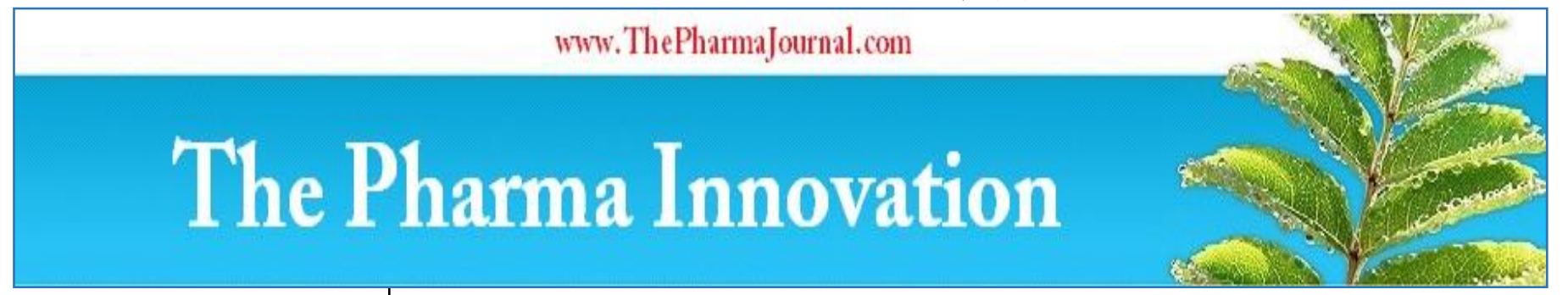

ISSN (E): 2277 - 7695

ISSN (P): 2349-8242

NAAS Rating: $\mathbf{5 . 0 3}$

TPI 2020; 9(11): 247-249

(C) 2020 TPI

www.thepharmajournal.com

Received: 26-09-2020

Accepted: $30-10-2020$

Subasri Mani

Ph.D., Scholar, Tamil Nadu

Agricultural University,

Coimbatore, Tamil Nadu, India

\section{An overview on wood apple (miracle fruit) and their properties}

\section{Subasri Mani}

DOI: $\underline{\text { https://doi.org/10.22271/tpi.2020.v9.i11d.5345 }}$

\section{Abstract}

The lesser known fruit crop wood apple (Feronia limonia L.) belongs to Rutaceae family is native to India but is also found in Sri Lanka, Malaysia, Cambodia, Thailand and other regions in the southern part of Asia. It is considered sacred by Hindus. It is not cultivated as commercial crop but it has religious importance in Southern India especially during Ganesh Chaturthi festival. Fruits contribute important nutritional and commercial value from the ancient time is being used in ayurvedic medicines as sole or contributing ingredient, but there is lack of published works in terms of depth scientific investigations about the fruit. So aims of this review to discuss the ecology, cultivation aspect and current level of utilization of this fruit.

Keywords: Feronia limonia, properties, fruit

\section{Introduction}

Feronia limonia which belongs to the family Rutaceae is commonly known as curd fruit, kathbel, elephant apple, and monkey fruit. In some parts of the world, this fruit is called elephant apple because it is a favorite food of elephants, while in other areas, it gets the name wood apple because of its hard wooden shell. The fruit ripens from early October through March. It is seasonally available and easily perishable fruit. It is cultivated in Indian states such as Maharashtra, Andhra Pradesh, Tamil Nadu, Kerala, Karnataka, Madhya Pradesh and the western Himalayas ${ }^{[1]}$.

\section{Tree Description}

Wood apple can be grown in dry tracts of tropical and sub-tropical regions right from sea level, up to $1400 \mathrm{~m}$ above MSL. It is small to moderate sized, deciduous, glabrous tree with thorny branches of girth about $0.6 \mathrm{~m}$ to $1.6 \mathrm{~m}{ }^{[2]}$. It is adapted to a wide range of soil conditions including degraded soil. It can also tolerate salinity to certain extent. It is an ideal tree to be exploited for growing in wasteland. The fruit is not under regular orcharding, however along the border of fields, roads, railways lines and as a roadside tree, near villages and banks of river are the most common places where the plants are found as stray plant. It grows well during monsoon and its tree grows up to 30 feet. It is very important to popularize its utilization and to harvest its medicinal values. There is no named or popular cultivar in wood apple. Propagation is done mainly by seed propagation and budding. Budded plants are dwarf and precocious in bearing ${ }^{[3]}$.

\section{Field preparation and planting}

The spacing of $8 \mathrm{mx} 8 \mathrm{~m}$ each pit with a size of $1 \mathrm{~m} \times 1 \mathrm{~m} \times 1 \mathrm{~m}$ is ideal. Planting should be done at the onset of monsoon after filling the pit with $20 \mathrm{~kg}$ FYM, sand and top soil. The basins should be formed immediately after planting in such a way that water harvesting is facilitated.

\section{Intercultural Operations}

Training is done by Central leader method allowing well spaced branches in all directions. For the additional benefits, intercrops can be taken during rainy seasons for the first 5 years. In the post monsoon season, the basins can be mulched with dry leaves.

Every year $25 \mathrm{~kg}$ of FYM is to be applied for each tree at the beginning of the monsoon rains. This will help in increasing fruit- size, taste and quality. During early stages of crop growth, if pot watering is done during summer it will be beneficial.

\section{Subasri Mani}

Ph.D., Scholar, Tamil Nadu Agricultural University, Coimbatore, Tamil Nadu, India 


\section{Pest Control}

Being a member of citrus family it is attacked by the leafeating caterpillar of citrus which completely defoliate the plant. Spraying of any contact insecticide should be done after hand picking and destruction of larvae.

\section{Harvest and yield}

Budded plants come to bearing 3-4 years after planting. But to reach optimum productivity it will take about 10 years. The crop flowers in February to May depending on the climatic conditions of a locality and fruits will be available from July to December depending on the flowering month. A well grown tree will give 200-250 fruits/year ${ }^{[4]}$.

\section{Fruit Description}

You might have heard the very popular saying that 'One apple a day keeps the doctor away', so this holds true even for wood apple. It is rich in nutrients and a great source of fibre, vitamins, calcium, phosphorous, protein, iron and betacarotene. Due to these reasons wood apple or bael fruit is a must have fruit. The edible fruits are $5-9 \mathrm{~cm}$ in diameter. Their shells are tough, and the inside consists of a brownish pulp and small white seeds. Each fruit weighs about 150 to $500 \mathrm{~g}$. The pulp represents 36 per cent of the whole fruit. Unripe wood apple pulp is pale gold color. Ripe fruits emit a sugary yet musky aroma. Ideal, fully ripe wood apples are light brown to toffee brown color.

Wood apple pulp has a remarkably long shelf life of two months if refrigerated (http://theindianvegan.blogspot.co.uk).
Wood apple is rich in acid, minerals and pectin. Wood apple pulp contains about $74 \%$ of moisture and $7.45 \%$ of carbohydrates. As wood apple is a highly under-utilized fruit, it can be preserved by making it as a processed food to use it during off-season. The seeds contain non-bitter oil and are high in unsaturated fatty acids ${ }^{[5]}$. The fruits contain phytochemicals (polyphenols, phytosterols, saponins, tannins, coumarins, and triterpenoids), vitamins and amino acids [6]. The presence of protein in a food is determined by the presence of essential amino acid in it. It was found that wood apple contains appreciable amount of protein. Amino acid present in wood apple include:

- Alanine

- Arginine

- Aspartic acid

- Glycine

- Histidine

- Isoleucine

- Leucine

- Phenylalanine

- Proline

- Tryptophan

- Tyrosine

- Valine

\section{Two types of Fruit}

1. Larger one with more sweet and

2. Smaller one with less sweet

Table 1: The Chemical Composition of Wood Apple Fruit (per 100g edible portion) ${ }^{[7]}$.

\begin{tabular}{|c|c|}
\hline Moisture (\%) & 74.00 \\
\hline Protein (\%) & 7.30 \\
\hline Carbohydrates (g) & 15.50 \\
\hline Fat (\%) & 3.7 \\
\hline Mineral Matter (\%) & 1.9 \\
\hline Calcium (\%) & 0.17 \\
\hline Phosphorus (\%) & 0.08 \\
\hline Iron (\%) & 0.07 \\
\hline Riboflavin (mg) & 170 \\
\hline Vitamin C (mg) & 2.00 \\
\hline Calcium $(\mathrm{mg})$ & 130 \\
\hline Carotene $(\mu \mathrm{g})$ & 6.1 \\
\hline Niacin $(\mathrm{mg})$ & 0.8 \\
\hline Thiamine $(\mathrm{mg})$ & 0.04 \\
\hline
\end{tabular}

\section{Medicinal Uses of Wood Apple Fruit}

- Every part of the fruit has got its medicinal property ${ }^{[8]}$.

- It is recommended as a remedy for chronic dysentery.

- The fruit especially used as a liver and cardiac tonic ${ }^{[9]}$.

- Unripe fruit is an effective treatment for hiccups, cough, sore throat and disease of the gums ${ }^{[10]}$.

- The trunk and branches of wood apple trees contain a gum-like substance called "Feronia gum". It is mostly used in curing diarrhea and dysentery.

- It is also recommended for people with peptic ulcer or piles since wood apple tree leaves contain tannin, which is known to reduce inflammation.

- The laxative property of wood apple also helps to avoid constipation and the subsequent, pain, discomfort and associated health risks of that condition.

- These attributes combined with the antifungal and antiphrastic activities make this fruit ideal for enhancing the digestive health. ${ }^{[11]}$

- It has curative value for various diseases of bones and joints, bilious diseases, controlling of capillary bleeding, cold, influenza, piles, dysentery, habitual constipation and scurvy.

- Juice of young leaves is given as a remedy for biliousness and intestinal troubles of children.

- Oil derived from the crushed leaves is applied on itch and the leaf decoction is given to children as an aid to digestion.

- Leaves, barks, roots and fruit pulp are all used against snakebite. ${ }^{[12]}$

\section{Processed Products of Wood Apple}

- The pulp can be eaten raw, but it is popularly scooped out and frozen or made into jam.

- It is used as an adjunct in jelly preparation along with the pulp of guava.

- It can also be mixed with coconut milk for a delicious, healthy beverage or frozen into an ice cream.

- Wood apple is well for digestion because it helps to 
destroy worms in the intestine and is a good for digestive disorders ${ }^{[13]}$

- It is widely used now a days in chutneys used with Katchouri in Hadoti region ${ }^{[14]}$.

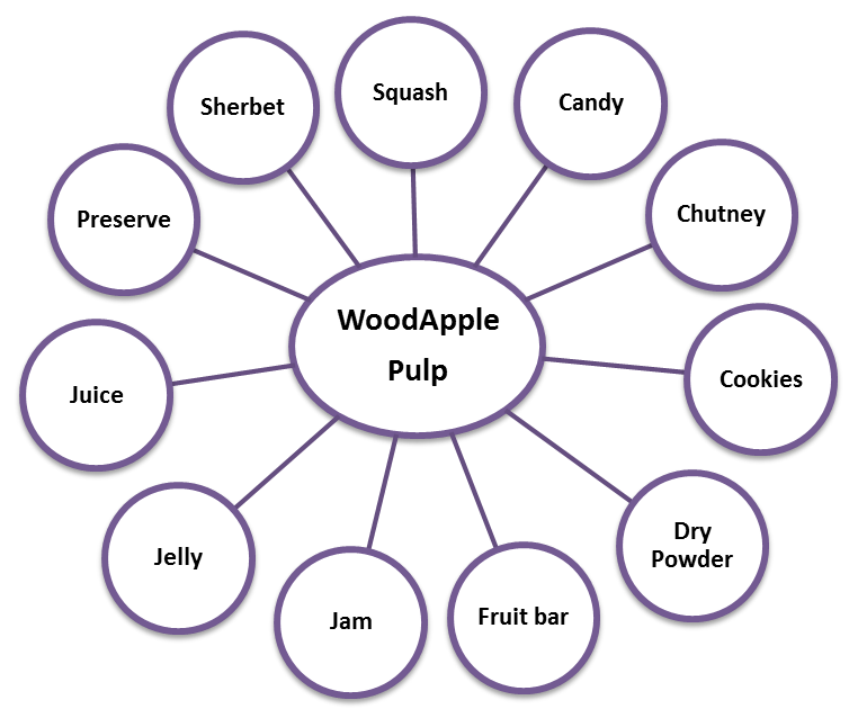

Different ways to eat wood apple ${ }^{[1]}$.

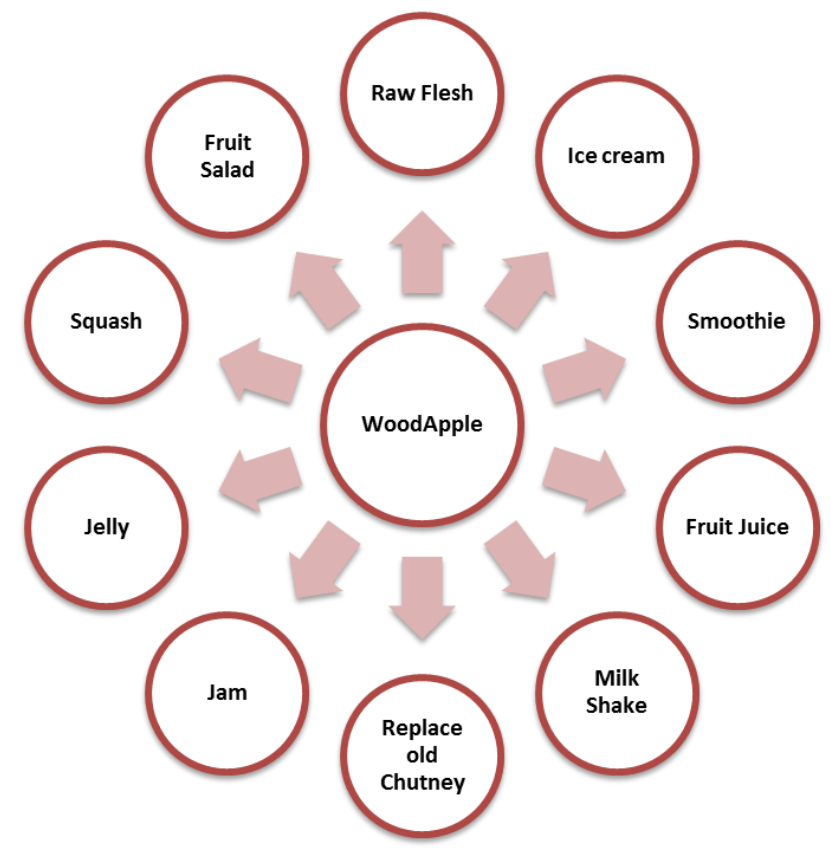

\section{Conclusion}

Poor diet can be said an invitation to multiple diseases. Fruit diet can prevent those diseases. By this we can prove what Hippocrates said, "Let food be thy medicine and medicine be thy food". Not only in fresh form but the underutilized fruit can also be utilized in dehydrated forms for making their availability year round to be taken by common people. Fruits provide all the essential nutrients such as vitamins and minerals. The value added products of the fruit need surge to catch the national and international markets if it is properly focused under nutritional care of inputs along with plant protection measures. The present overview on this fruit crop is mainly emphasis on nutritional, food and medicinal value and its impact on betterment of human health wellness through intake of vitamins, minerals, total sugars and ascorbic acid content. In spite of their high nutritional and medicinal values, their commercial cultivation is lacking and needs to be popularized for commercial acceptance and orchard establishment under arid and semi-arid zones to attain sustainability in fruit production.

\section{References}

1. Tripti Y, Deepak V, Shweta S, Soumitra T, Sindhu. Wood apple-Its nutritive value and medicinal benefits. International Journal of Agricultural Engineering 2018;11:159-163.

2. Troup RS. In: The Siliviculture of Indian Trees, Vol. III, Govt. of India, Pub 1921, pp.101-103.

3. Jebas S, Arun S, Merish S, Walter TM. The Versatile Vila (Wood Apple) with special reference to Siddha Medicine. Siddha Papers 2015;2(4).

4. Pareek OP, Sharma S. Underutilized Fruits and Nuts, Aavishkar Publishers, Distributors, Jaipur 2009, pp.156.

5. Singh D, Chaudhary M, Chauhan PS, Prahalad VC, Kavita A. Value addition to forest produce for nutrition and livelihood. The Indian Forester 2009, pp: 1271-1287.

6. Singh Jagdev. Wood apple, Ayur Times 2015.

7. Yogendra S, Prerak B. An Overview on Inherent Potential of Underutilized Fruits, Int. J. Pure App. Biosci 2019;7(3):86-103.

8. Morton J. Wood Apple. In: Fruits of Warm. Florida Flare Books 1987, pp. 190-191.

9. Chopra CS, Singh RP. Studies on the extraction of pulp from wood apple (Feronia acidissima) fruit. Beverage and Food World 2001;28(2):25-27.

10. Anonymous. Official Methods of Analysis of the Association of Official Analytical Chemists, 20th Edition 2005. Washington, D.C.

11. Singh U, Kochhar A, Boora R. Proximate composition, available carbohydrates, dietary fibers and anti-nutritional factors in bael (aegle marmelos) leaf, pulp and seed powder. International Journal of Scientific and Research Publications 2012;2(4):1-4.

12. Ahamed SM, Swamy SK, Jayaverra KN, Rao JV, Kumar S. Anti inflammatory, antipyretic and analgesic activity of methanolic extract of Feronia limonia. Pharmacology 2008;3:852-857.

13. Nithya N, Saraswathi U. In vitro antioxidant and antibacterial efficacy of Feronia elephantum Correa fruit. Indian J Natural Products and Resources 2010;1(3):301305.

14. Patel DK, Kumar R, Laloo D, Hemalatha S. Diabetes mellitus: An overview on its pharmacological aspects and reported medicinal plants having ant diabetic activity. Asian Pac. J. Trop. Biomed 2012;2(5):411-420. 